\title{
Chronic Inflammatory Infiltrate
}

National Cancer Institute

\section{Source}

National Cancer Institute. Chronic Inflammatory Infiltrate. NCI Thesaurus. Code C35980.

A morphologic finding indicating the presence of reactive lymphocytes,

lymphoplasmacytic cells, and/or reactive plasma cells in a tissue sample. 